\title{
The effect of feed rations containing high moisture crimped corn ensiled with microbial inoculant or chemical additive on milk production and metabolism of dairy cows
}

\author{
László Könyves ${ }^{1}$, Pál Rafai ${ }^{1}$, Harry Miettinen ${ }^{2}$, Péter Kovács ${ }^{1}$, Viktor Jurkovich ${ }^{1}$, \\ Endre Brydl ${ }^{1}$
}

\author{
${ }^{1}$ Szent István University, Faculty of Veterinary Science, Department of Animal Hygiene, Herd-health \\ and Veterinary Applied Ethology, Budapest, Hungary \\ ${ }^{2}$ Nöykkiönlaaksontie, Espoo, Finland \\ Received March 17, 2015 \\ Accepted November 10, 2015
}

\begin{abstract}
The study evaluated the effects of crimped corn preserved either with organic acids or with a microbial inoculant on a range of metabolic and production indicators of dairy cows. Two hundred and sixty in-calf, second and third parity cows were selected into pairs on basis of age, parity, milk production in previous lactation, days in milk and body condition score with the greatest possible conformity within pairs. Cow pairs were assigned into a 2-period crossover experiment $(2 \times 45$ days $)$ and kept in separate groups within the same shed. Dietary treatments were TMR with crimped corn preserved with either organic acids (treatment $\mathrm{K}$ ) or microbial inoculant (treatment B). Ten superbly matched cow-pairs were selected to form nucleus pairs for metabolic studies. The preservatives had no effect on the nutrient content of crimped corn. Crimped corn preserved with the microbial inoculant were found mouldy, predominantly with Mucor sp. at a number high enough to inhibit the growth of lactic acid bacteria, and had significantly higher $\mathrm{pH}$ and ammonium concentration compared to the chemical treatment. The milk yield of treatment $\mathrm{K}$ cows was significantly higher than that of treatment B cows with identical feed intake. Blood beta-hydroxy-butyrate concentration was lower and blood aspartate amino transferase activity higher with treatment $\mathrm{K}$ compared to treatment B. Results of this study suggest the superiority of total mixed rations containing chemically preserved crimped corn in terms of ammonia and microbiological indicators of crimped corn, significantly higher milk yield, and balanced energy metabolism.
\end{abstract}

Crimping, corn preservation, organic/microbial preservatives, energy and protein metabolism

Concentration and availability of nutrients in cereal grains reach optimum at $35-45 \%$ moisture content of kernels. Crimping (crushing and preservation of grain commodities with high moisture content by anaerobic fermentation with/without preservatives) has been developed for conservation of nutrients at the best stage of plant development.

Experiments have been conducted to study the effects of different silage additives on the nutritive value, microbiological and fermentation characteristics of ensiled crimped corn (Galic et al. 2008; Biro et al. 2009; Galic et al. 2010; Juracek et al. 2010). The effect of crimped corn on steers and fattening bulls has also been studied (Vance et al. 1972). However, little research has been conducted to study the effects of crimped corn on milk production, metabolism, and health of dairy cows. Encouraging results of an earlier study (Brydl et al. 2009) prompted us to investigate the effects of TMR (total mixed ration) containing crimped maize preserved either with organic acids or with a microbial inoculant on a range of metabolic and production indicators of dairy cows.

\section{Materials and Methods}

The experiment was carried out on a large-scale dairy farm with 1600 cows and progeny, where one of the 8 cow sheds was emptied for the experiment. The shed was divided into two barns (referred to as Barn 1 and

Address for correspondence:

Prof. Dr. Pál Rafai

Faculty of Veterinary Science

Szent István University

E-mail: rafai.pal@aotk.szie.hu

Pf. 2,1400 Budapest, Hungary

http://actavet.vfu.cz/ 
Barn 2) by a central feeding passage with feed manger on either side, with feed stands in front of the mangers, dunging passage and chopped straw littered cubicles. During the experiment 130 cows were housed in both of the two barns with $9.5 \mathrm{~m}^{2} / \mathrm{cow}$ stocking density. Clean, fresh water was provided from temperature and level controlled basins.

A total of 260 in-calf, second/third parity cows were selected into pairs on the basis of age, parity, milk production in previous lactation, DIM (days in milk) and BCS (body condition score). Members of the cow-pairs were randomly divided into one of two experimental groups and housed in the same shed in either of the two barns with identical stocking and feeding condition. Ten cow-pairs of the highest possible similarity (nucleus pairs) were chosen for metabolic studies. The number of the cows that remained in the groups from the beginning till the end of the experiment was 74 (Barn 1) and 89 (Barn 2). Data of these cows were used for analysis. At the start of the experiment the number of lactation, milk yield in the previous lactation and DIM of the 74 cows in Barn 1 and 89 cows in Barn 2 was 1.76 and $1.70(P<0.56) ; 9,877$ and 9,847 kg/305 days $(P<0.58) ; 33.3$ and $27.7(P<0.48)$, respectively.

Corn harvested from the same field with about $30 \%$ moisture content was crimped with ROmiLL CP2 mobile roller crusher (ROmiLL, Czech Republic) and treated either with a chemical preservative (Treatment K) or with a microbial inoculant (Treatment B) at the rate recommended by the manufacturers. The crimped materials were ensiled in plastic bags of 2 metre diameter. The main components of the chemical additive and microbial inoculant included buffered formic, propionic and benzoic acid with ammonium formate (Kemira AIV 2000 Plus/KemiSile Crimp) and lactobacilli including L. buchneri (BiocrimpBiotal Ltd), respectively.

Daily ration of experimental groups contained $3 \mathrm{~kg}$ of crimped corn preserved with either of the additives and was formulated to have iso-energetic and iso-nitrogenic content. The component of the rations was collected by weight into a mixer wagon (RMH VS14, RMH, Lachish Industries, LTD., Israel) to prepare TMR which were then distributed to the cows two times a day. Because no appreciable amount was left in the mangers, the mean feed intake of the group equalled with what was offered. Daily rations of TMR were calculated according to the average milk yield, DIM, body weight and BCS of the experimental groups and updated by 4 week intervals.

The experiment was arranged into two periods of 45 days in a cross-over design. The first two weeks of the 45-day experimental period served as a preliminary period that allowed adaptation to the feeding regime. The following 30 days served for observation and samplings. At the end of the first period the feeding regime was exchanged (cross-over), viz. the cows that had received treatment $\mathrm{K}$ had treatment $\mathrm{B}$ for the following 45 days and vice-versa. This second 45-day period had been split also into a fortnight preliminary and a 30 day observation period. Between the two parts of the experiment a 6 day transient period was inserted that allowed a gradual shift between the feeding regimes.

Eleven feed samples were taken at regular intervals and subjected for microbiological and chemical examination according to the relevant regulation of EU (Commission Regulation (EC) No 152/2009 of 27 January 2009).

Cows were milked twice a day in a central milking parlour equipped with Westfalia Dairy Plane Autorotor milking automat (GEA Farm Technologies, Germany) that recorded the individual milk yield of the cows per milking. Daily milk yield, SCC (somatic cell count), protein and fat content of the milk samples were officially measured and verified by the Hungarian Dairy Herd Recording Ltd once a month. Data of these independent records were used in evaluation of the present experiment.

Fluid from the rumen and blood from the subcutaneous abdominal vein were collected from the nucleus cows on days $1,7,14,21$, and 28 of the respective experimental periods, each time $3 \mathrm{~h}$ after the morning feeding. Rumen fluid was sampled into glass bottles by Dirksen tubes with special efforts to avoid contamination with saliva. Blood samples were collected into heparinised glass tubes. Rumen fluid and blood samples were cooled to $4{ }^{\circ} \mathrm{C}$ and transported with no delay to the laboratory for further analysis.

Rumen fluid samples were used for determination of $\mathrm{pH}$ (by a $\mathrm{pH}$ electrode), ammonia, VFAs (volatile fatty acids) and LA (lactic acid). Cryogenic samples $(2.5 \mathrm{ml})$ were acidified with $25 \%$ metaphosphoric acid $(0.5 \mathrm{ml})$, centrifuged, and filtered and the sample containing internal standard (2-ethyl butyric acid) was injected directly on to a column of a Shimadzu GC2010 (Flame ionisation detector) with AOC20S autosampler Column Type: Stabilwax $30 \mathrm{~m} \times 0.25 \mathrm{~mm} \times 0.25 \mu \mathrm{m}$ (Restek, USA).

The effect of feeds on the energy and protein metabolism and liver indicators was followed by measuring the blood/plasma concentration of glucose, BHB (beta-hydroxy-butyrate), NEFA (non-esterified fatty acids), urea, total protein and AST (aspartate amino transferase) activity by spectrophotometric methods (Biosystems A25 Chemistry Analyzer, Diamond Diagnostics, Holliston, MA, USA.)

\section{Statistical analysis}

The effect of treatments on milk production, rumen fluid and metabolic indicators was analysed by linear mixed-effects model. Due to the crossover design of the experiment the dependent variables in the two actual experimental periods were analysed by a model (Senn 2002) using the formula below:

$\mathrm{Y}_{\mathrm{ijn}}=\mu+\mathrm{T}_{\mathrm{i}}+\mathrm{P}_{\mathrm{j}}+\mathrm{C}_{\mathrm{ijn}}+\boldsymbol{\varepsilon}_{\mathrm{ij}}$

where $\mathrm{Y}_{\mathrm{iin}}$ is the daily milk yield (rumen fluid, metabolic indicators) of the $n^{\text {th }}$ cow; $\mu$ is the overall mean; Tis the fixed effect of the $i^{\text {th }}$ treatment $(i=1,2) ; \mathrm{P}_{\mathrm{j}}$ is the fixed effect of $j^{\text {th }}$ period $(j=1,2) ; \mathrm{C}_{\mathrm{ijn}}$ is the random effect of the $n^{\text {th }}$ cow within the $i^{\text {th }}$ treatment and $j^{\text {th }}$ period; $\varepsilon_{\mathrm{inn}}$ is the residual error. The differences among the means of $\mathrm{pH}$ of crimped corn were studied with exact Wilcoxon Mann-Whitney rank sum test. 


\section{Results}

The nutrient content of parallel samples (data are not disclosed) showed no significant differences apart from the ammonium concentration of treatment B crimped corn samples that was significantly higher $(P<0.04)$ than in counterpart samples. Concentrations of VFAs (volatile fatty acids including acetic-; propionic-; iso-butyric-; butyric-; iso-valeric-; valeric-; capronic- and lactic-acid) were also measured in the above mentioned samples and no differences were found. The $\mathrm{pH}$ of crimped corn with treatment $\mathrm{B}$ was higher than with treatment $\mathrm{K}(4.4 \pm 0.42$ vs $3.78 \pm 0.11 ; P<0.001)$.

At the start of the experiment, bags of crimped corn were opened and at all consecutive samplings the grain in the treatment B bag were found mouldy, predominantly with Mucor species (data are not shown). No adverse clinical signs attributable to feeding mouldy crimped corn were observed in spite of the fact that unaffected and mouldy parts of treatment B crimped grain were equally incorporated into the experimental diet.

Both the treatment and the period of the experiment had a significant $(P<0.001)$ effect on the milk yield (Table 1). The intercept represents the average milk yield (kg/day) of treatment B cows. The coefficient of the treatment is interpreted as the increment of daily milk yield $(\mathrm{kg})$ of treatment $\mathrm{K}$ cows over treatment B cows $(0.94 \mathrm{~kg} /$ day $)$. On this basis the average milk production of treatment $\mathrm{B}$ and treatment $\mathrm{K}$ cows was found to be 38.09 and $39.03 \mathrm{~kg} /$ day, respectively, in the first period of the experiment. The coefficient of the period indicates that (mainly) due to seasonal variability of lactation treatment $\mathrm{K}$ cows outperformed treatment B cows by $0.32 \mathrm{~kg}$ milk/day, viz. the actual daily milk production of an average treatment $\mathrm{B}$ and treatment $\mathrm{K}$ cow was 38.41 and $39.35 \mathrm{~kg}$, respectively. In the second period both numbers increased by $0.32 \mathrm{~kg} /$ day additional milk production. Combination of the coefficients indicates that the difference between daily milk production of an average treatment $\mathrm{K}$ cow in period 2 and treatment $\mathrm{B}$ cow in period 1 amounts to $1.26 \mathrm{~kg} /$ day.

Table 1. Impact of treatment and period on milk production analysed by mixed effect model.

\begin{tabular}{lcccc}
\hline Response & Predictor $^{1}$ & $P^{2}$ & Coefficient $^{3}$ & Intercept $^{4}$ \\
\hline Milk yield, kg/d & Treatment & $<0.001$ & 0.94 & 38.09 \\
& Period & $<0.001$ & 0.32 & \\
\hline
\end{tabular}

${ }^{1}$ Regression term

${ }^{2} P=$ Probability for effect of regression term

${ }^{3}$ Coefficient of the regression term

${ }^{4}$ Intercept of the regression equation

Concentrations of milk fat in periods 1 and 2 varied between $3.6-3.8 \%$ and $2.8-2.9 \%$, respectively. Milk protein showed minor variability (2.9-3.0\%). The SCC of cows fed TMR with treatment K crimped corn was numerically $\left(259.9\right.$ and $338.3 \times 10^{3} / \mathrm{ml}$ in periods 1 and 2 , respectively), but not significantly lower than that of the treatment B cows (435.0 and $424.1 \times 10^{3} / \mathrm{ml}$, respectively). Milk fat or protein concentrations were not significantly different between the treatments.

Effects of Treatment B and $\mathrm{K}$ on indicators of the rumen fluid, energy- and proteinmetabolism and integrity of the liver are summarised in Table 2. The rumen fluid indicators were not significantly different between the treatments. Rumen acetate, propionate, and butyrate concentrations were significantly higher in period 2 compared to period 1 .

The treatment had a significant effect $(P<0.05)$ on blood concentrations of BHB and AST. Blood BHB concentration was lower and blood AST activity was higher with treatment $\mathrm{K}$ compared to treatment B (Table 2). The period had a significant effect on blood 
glucose, NEFA, AST, and total protein contents. Blood glucose, AST, and total protein concentrations were higher, and NEFA concentration was lower in period 2 compared to period 1.

Table 2. Indicators of the rumen fluid, energy- and protein-metabolism and liver integrity.

\begin{tabular}{|c|c|c|c|c|}
\hline Response & Predictor $^{1}$ & $P^{2}$ & Coefficient $^{3}$ & Intercept $t^{4}$ \\
\hline \multicolumn{5}{|c|}{ Indicators of the rumen fluid } \\
\hline \multirow[t]{2}{*}{ Rumen fluid $\mathrm{pH}$} & Treatment & 0.93 & 0.00 & 6.51 \\
\hline & Period & 0.70 & -0.02 & \\
\hline \multirow[t]{2}{*}{ Acetate, $\mathrm{mmol} / \mathrm{l}$} & Treatment & 0.76 & 1.23 & 53.44 \\
\hline & Period & $<0.001$ & 21.23 & \\
\hline \multirow[t]{2}{*}{ Propionate, $\mathrm{mmol} / \mathrm{l}$} & Treatment & 0.69 & 0.77 & 20.66 \\
\hline & Period & $<0.01$ & 6.63 & \\
\hline \multirow[t]{2}{*}{ Acetate/propionate ratio } & Treatment & 0.40 & -0.08 & 2.84 \\
\hline & Period & $<0.05$ & 0.23 & \\
\hline \multirow[t]{2}{*}{ Butyrate, mmol/1 } & Treatment & 0.56 & -0.47 & 9.29 \\
\hline & Period & $<0.001$ & 3.64 & \\
\hline \multirow[t]{3}{*}{ Ammonium, mmol/1 } & Treatment & 0.88 & -0.07 & 6.49 \\
\hline & & tors of $\mathrm{e}$ & & \\
\hline & & $\mathrm{n}$ and $\mathrm{AS}$ & & \\
\hline \multirow[t]{2}{*}{ Glucose, mmol/1 } & Treatment & 0.850 & -0.02 & 2.89 \\
\hline & Period & $<0.001$ & 0.32 & \\
\hline \multirow[t]{2}{*}{$\mathrm{BHB}, \mathrm{mmol} / 1$} & Treatment & $<0.05$ & -0.08 & 0.41 \\
\hline & Period & 0.78 & 0.01 & \\
\hline \multirow[t]{2}{*}{$\mathrm{NEFA}, \mathrm{mmol} / 1$} & Treatment & 0.30 & -0.04 & 0.49 \\
\hline & Period & $<0.001$ & -0.15 & \\
\hline \multirow[t]{2}{*}{ AST activity, U/1 } & Treatment & $<0.05$ & 3.52 & 83.88 \\
\hline & Period & $<0.01$ & 4.87 & \\
\hline \multicolumn{5}{|c|}{ Indicators of protein metabolism } \\
\hline Urea, mmol/1 & Treatment & 0.34 & -0.13 & 6.78 \\
\hline \multirow[t]{3}{*}{ Total protein, g/1 } & Period & 0.33 & 0.14 & \\
\hline & Treatment & 0.23 & 1.60 & 88.46 \\
\hline & Period & $<0.05$ & 3.55 & \\
\hline
\end{tabular}

${ }^{1}$ Regression term

${ }^{2} P=$ Probability for effect of regression term

${ }^{3}$ Coefficient of the regression term

${ }^{4}$ Intercept of the regression equation

$\mathrm{AST}=$ aspartate amino transferase $; \mathrm{BHB}=$ beta-hydroxy-butyrate; $\mathrm{NEFA}=$ non esterified fatty acids

\section{Discussion}

In the present experiment the dry matter (DM) content of treatment $\mathrm{B}$ and $\mathrm{K}$ crimped corn samples was somewhat higher than reported by Biro et al. (2009) and Doležal and Zeman (2005). Concentrations of other nutrients as expressed in $\mathrm{g} / \mathrm{kg}$ of dry matter including crude protein, fat, crude fibre, starch and nitrogen free extract were similar to those reported by Biro et al. (2009) for crimped corn ensiled without additives, or comparable to data reported by Wardynski et al. (1993).

The success of ensiling high moisture crimped corn depends on a rapid decrease of $\mathrm{pH}$ and provision of anaerobic conditions. Microbiological inoculants, including homo- and 
hetero-fermentative lactic acid bacteria have been used recently to improve the fermentation processes and to improve the aerobic stability of the ensiled crimped grains. Homofermentative bacteria (e.g. Lactobacillus plantarum, Lactococcus lactis, Enterococcus faecium, Lactococcus salivarius and others) are used predominantly for decreasing the $\mathrm{pH}$ via enhanced lactic acid production; others (e.g. Propionibacteria sp., Lactobacillus buchneri etc.) are involved in such inoculants for increasing the aerobic stability (Davies 2010). Another approach is the use of organic acids. A mixture of ammonium formate, propionate, and benzoate was found effective in reducing $\mathrm{pH}$ and increasing the residual sugar content of crimped grain (Adesogan et al. 2003). In the present experiment the corn was harvested synchronously from the same field and processed identically with both treatments.

The chemical additive in the present experiment decreased efficiently the $\mathrm{pH}$ of the ensiled crimped corn and the mean value was found significantly lower than that provided with the microbial inoculant. Lactobacillus buchneri has been shown to inhibit the aerobic deterioration of silages through producing organic acids other than lactic acid, mainly acetic acid (Davies 2010). According to Driehuis et al. (2001) treatment with Lactobacillus buchneri may inhibit the aerobic deterioration of silage. However, the effect has not always been consistent (Kleinschmit and Kung 2006). This is supported by our finding that crimped corn ensiled with the bacterial inoculant was found mouldy, predominantly infected with Mucor sp. The higher bacteria and Mucor sp. counts may explain the higher $\mathrm{pH}$ and also the significantly higher ammonium concentration of the treatment $\mathrm{B}$ crimped corn samples.

The mould (Mucor sp.) contamination seemed not to affect palatability of the TMR as indicated by the similar consumption of the daily rations in treatments B and K. Although Mucor species might be allergenic in humans, to our knowledge neither of the known species of the Mucor genus produces compounds toxigenic for bovines.

Earlier experiments demonstrated no differences in the yield and composition of milk from dairy cows when dry grain was replaced with ensiled high moisture grain (Miettinen and Li 2009). The milk production of our treatment $\mathrm{K}$ cows was significantly superior to that of treatment B cows. Due to this and to the identical nutrient content of the experimental feeds; the considerable difference in the milk yield might be attributed to the difference in quality of crimped corn grain or in utilisation of nutrients.

In their early studies Clark and Harsberger (1972) and McKnight et al. (1973) demonstrated higher DM, organic matter (OM) and starch digestibility of high moisture ensiled corn diets in comparison with dried corn diets. Starch digestibility in lambs fed additive-treated crimped wheat was found greater than in lambs fed untreated crimped wheat (Adegosan et al. 2003).

This may be associated with the fermentation acids present in additive-treated crimped wheat (Miettinen and Li 2009). In the experiments of Adegosan et al. (2003) the chemical additive produced numerically higher coefficients of DM, OM and crude protein digestibility than the microbiological inoculants. Mould (2007b) compared the in vitro rate of fermentation of ensiled high moisture crimped corn preserved either with two microbial inoculants or with a chemical additive and found $24 \%$ higher fermentation rate and cumulative gas product at short incubation periods with the chemical additive. The effect of chemical additives was associated with the preservation of readily degradable materials and speculated that chemical additives enable greater proportion of grain to be degraded in the rumen. However, this finding may not apply to corn. In another study when maize was ensiled with an inoculant consisting of lactic acid- and propionic acid-producing bacteria Mould (2007a) found a higher fermentation rate and cumulative gas production compared to corn ensiled with a chemical additive. The different effects of biological and chemical preservatives on crimped corn and wheat justify further studies. 
In the present experiment we did not find differences in the $\mathrm{pH}$ and concentrations of constituents of the rumen fluid attributable to the treatments. The experimental period had significant effect on the concentrations of acetate, propionate, and butyrate and on the acetate/propionate ratio, all of which were higher during period 2. Both mean values of the these rumen indicators as expressed by the intercepts in Table 2 and contracted values (intercept \pm coefficient) of these indicators fell within the range of values accepted as normal for high producing dairy cows (Gaál 1999). Lower blood BHB concentration with treatment $\mathrm{K}$ compared to treatment B may indicate more balanced energy metabolism of the cows fed diet $\mathrm{K}$. The higher glucose concentration and lower NEFA concentration in period 2 indicates better energy balance of the cows during this period. The mean concentration of BHB (0.41 mmol/l) was found normal $(<0.8 \mathrm{mmol} / \mathrm{l}$; Gaál 2009). Both the mean concentration of NEFA $(0.49 \mathrm{mmol} / \mathrm{l})$ and AST activity $(83.88 \mathrm{IU} / \mathrm{l})$ was higher than the accepted normal value $(<0.2 \mathrm{mmol} / \mathrm{l}$ and $<80 \mathrm{IU} / \mathrm{l}$, respectively; Gaál 1999). The total protein and urea concentrations in plasma $(88.46 \mathrm{~g} / 1$ and $6.78 \mathrm{mmol} / \mathrm{l}$, respectively) were slightly above the accepted normal indices $(65-85 \mathrm{~g} / \mathrm{l}$ and $3.3-5.0 \mathrm{mmol} / \mathrm{l}$, respectively; Gaál 2009).

Results of the present study suggest the superiority of TMR containing chemically preserved crimped corn in terms of chemical (ammonia) and microbiological indicators of crimped corn, resulting in significantly higher milk yield and balanced energy metabolism.

\section{Acknowledgement}

Part of this research was supported by the TÁMOP-4.2.1.B-11/2/KMR-2011-003 project.

\section{References}

Adesogan AT, Salawu MB, Ross AB, Davies DR, Brooks AE 2003: Effect of Lactobacillus buchneri, Lactobacillus fermentum, Leuconostoc meseteroides inoculants, or chemical additive on the fermentation, aerobic stability, and nutritive value of crimped wheat grains. J Dairy Sci 86: 1789-1796

Biro D, Galik B, Juracek M, Simko M, Strakova E, Michalkova J, Gyongyova E 2009: Effect of biological and biochemical silage additives on final nutritive, hygienic and fermentation characteristics of ensiled high moisture crimped corn. Acta Vet Brno 78: 691-698

Brydl E, Tirian A, Könyves L, Jurkovich V, Tegzes L, Farkas R, Horvath L, Török M, Karnoth J, Miettinen HH 2009: Comparison of the effect of feeding crimped and dry corn grain in high producing dairy cows. Folia Vet 53: $65-69$

Clark JH, Harsberger KE 1972: High-moisture corn versus dry corn in combination with either corn silage or hay for lactating cows. J Dairy Sci 55: 1474-1480

Commission Regulation (EC) No 152/2009 of January 2009 laying down the methods of sampling and analysis for the official control on feed. OJ L 54, February 26, 2009

Davies DR 2010: Silage inoculants -where next? In: $14^{\text {th }}$ International Symposium of Forage Conservation, March 17-19, 2010 Brno. Eds: Jambor V, Jamborová S, Vosynková B, Procházka P, Vosynková D, Kumprechtová D. Mendel University Brno, Czech Republic, pp. 32-39

Driehuis FSJ, Oude Elferink WH,VanWikselaar PG 2001: Fermentation characteristics and aerobic stability of grass silage inoculated with Lactobacillus buchneri, with or without homofermentative lactic acid bacteria. Grass Forage Sci 56: 330-343

Doležal P, Zeman L 2005: Effect of different forms of bacterial inoculants on the fermentation process of ensiled crushed maize moisture grains. Czech J Anim Sci 50: 201-207

Galik B, Daniel B, Miroslav J, Milan S 2008: Influence of silage additives on fermentation of high moisture crimped corn. JCEA 9: 439-444

Gaál T 1999: Állatorvosi klinikai laboratóriumi diagnosztika (Veterinary Laboratory Diagnostics, in Hungarian), Sík kiadó, Budapest, Hungary 1999

Galik B, Biro D, Juracek M, Simko M, Michalkova J 2010: Comparison of the energy contents of high moisture corn silages obtained by various methods. Acta Fytotechnica et Zootechnica 13: 57-59

Juracek M, Biro D, Simko M, Galik B, Rolinec, M, Sevcik P, Kuruc M 2010: Energy value of high moisture crimped corn silages. Acta Fytotechnica et Zootechnica 13: 36-39

Kleinschmit DH, Kung L 2006: The effects of Lactobacillus buchneri 40788 and Pediococcus pentocaseous R1094 on the fermentation of corn silage. J Dairy Sci 89: 3999-4004

McKnight DR, Macleod GK, Buchanan-Smith JG, Movat DN 1973: Utilization of ensiled or acid-treated high-moisture corn by cattle. Canad J Anim Sci 53: 491-496 
Miettinen H, Li L 2009: The advantages of feeding ensiled high-moisture grain to livestock. Recent Advances in Animal Nutrition-Australia 17: 1-6

Mould FL 2007a: An evaluation of the effect of crimping cereal grains on their nutritional characteristics using both biochemical and in vitro assessments. Part I: Maize. School of Agriculture, Policy and Development, University of Reading, Reading, UK

Mould FL 2007b: An evaluation of the effect of crimping cereal grains on their nutritional characteristics using both biochemical and in vitro assessments. Part II: Wheat. School of Agriculture, Policy and Development, University of Reading, Reading, UK

Senn S 2002: Cross-Over Trials in Clinical Research. $2^{\text {nd }}$ edn. John Wiley \& Sons. ISBN: 978-0-471-49653-3

Vance RD, Preston RL, Klosterman EW, Cahill VR 1972: Utilization of whole shelled and crimped corn grain with varying proportions of corn silage by growing-finishing steers. J Anim Sci 35: 598-605

Wardynski FA, Rust SR, Yokoyama MT 1993: Effect of microbial inoculation of high moisture corn on fermentation characteristics, aerobic stability, and cattle performance. J Anim Sci 71: 2246-2252 